http://revped.ise.ro

Print ISSN 0034-8678; Online ISSN: 2559 - 639X

\title{
REFERENCE POINTS IN CURRICULUM DESIGN: GEOGRAPHY AS A SCHOOL SUBJECT
}

\section{ELEMENTE DE REFERINŢĂ PENTRU PROIECTAREA UNUI CURRICULUM} DISCIPLINAR: GEOGRAFIE

\section{Octavian MÂNDRUT}

\author{
Journal of Pedagogy, 2017 (2), 41 - 59 \\ https://doi.org/10.26755/RevPed/2017.2/41
}

The online version of this article can be found at: http://revped.ise.ro/category/2017-en/

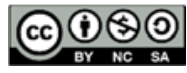

This work is licensed under the Creative Commons Attribution-NonCommercial-ShareAlike 4.0 International License. 94042, USA.

Published by:

\section{INSTITUTUL DE ȘTIINȚE ALE EDUCAȚIEI}

http://www.ise.ro/

Further information about Revista de Pedagogie - Journal of Pedagogy can be found at:

Editorial Policy: http://revped.ise.ro/editorial-policy/

Author Guidelines: http://revped.ise.ro/the-writer-guide-2/ 


\section{ELEMENTE DE REFERIN Ă PENTRU PROIECTAREA UNUI CURRICULUM DISCIPLINAR: GEOGRAFIE}

\section{Rezumat}

Octavian MÂNDRU *

Studiul de fa ă are un caracter teoretic şi exploratoriu. Îşi propune să descrie un sistem referen ial care ar trebui să determine sau să influen eze deciziile de construire a unui nou curriculum. Exemplul disciplinar al geografiei (sau, mai larg, al unui domeniu de studiu intitulat "geografie - mediu înconjurător") are elemente specifice rezultate din caracteristicile structurii interioare. Sistemul referen ial poate fi modificat, redus, extins, taxonomizat sau adaptat în raport cu alte discipline sau domenii de studii, cel pu in asemănătoare. Exemplul curriculumului „vertical” al geografiei (V - XII) are la bază un sistem de finalită i (competen e), progresul acestora (pe niveluri şi vârste) şi depinde de orizontul de timp al proiectării, rezultând variante posibile diferite. Tipul de curriculum este însă foarte dependent de paradigma construc iei sale: predominant ştiin ifică (eventual cu o inser ie umană individuală minimă) sau predominant subiectivă, ca rezultat al unor păreri individuale sau de grup, mai mult sau mai pu in legitimate.

Cuvinte-cheie: competen e; curriculum; domenii de studiu; geografie; mediu înconjurător.

\section{Abstract}

This study is theoretical and exploratory. It aims to describe a reference system which should determine or influence the decisions for the new curriculum design. The example of geography as a subject matter (or, in a wider perspective, of a field of study called "Geography - Environmental Studies") reveals specific elements resulting from the characteristics of the interior structure. The reference system may be altered, reduced, amplified, categorized or adjusted with respect to other subjects or fields of study, that are at least similar. The example of the "vertical" curriculum of Geography (grades $V-X I I)$ relies upon a system of outcomes (competencies) in progression (according to levels and ages) and it depends on the time horizon of the design. Consequently, different options might come out within the process. Nevertheless, the curriculum depends a lot on the paradigm of its design: with a scientific dominance (with a likely minimal individual human insertion) or with a subjective touch, as a result of some individual or group opinions which are more or less justified.

Keywords: competences; curriculum; environmental studies; fields of study; geography.

\footnotetext{
* Cercet. şt. dr., Universitatea de Vest „Vasile Goldiş” din Arad, România; octavianmandrut@yahoo.com
} 


\section{Reperele teoretice ale unui cadru de proiectare}

Proiectarea unui curriculum, stabilirea finalită ilor şi a decupajelor interioare ale disciplinelor şcolare (pe vârste, clase, teme, capitole) presupune existen a unui cadru referen ial generator, care să aibă elemente justificative.

Reperele teoretice redate în continuare reprezintă, în acest moment (2017), cadrul contextual teoretic cel mai larg al încercării de inovare a unui curriculum şcolar disciplinar de geografie. Acest cadru teoretic este rezultatul unei succesiuni de ini iative exploratorii (cu origini în perioada 1976 - 1979), adaptate şi ameliorate în timp $(2010,2012,2015,2016,2017)$ în raport de evolu iile contextuale ale învă ământului, ştiin elor educa iei şi ale geografiei.

Sistemul de proiectare a structurii verticale (de la prima la ultima clasă de studiere) pe care poate să o aibă o disciplină şcolară este raportabil la o serie de repere; acestea determină sau influen ează curriculum şcolar „vertical” în componentele sale semnificative.

Principalele lucrări recente $(2012$ - 2017) care abordează şi această temă sunt:

- "Coordonate ale unui nou cadru de referin ă al curriculumului na ional' (coord. D. Potolea, Steliana Toma, Anca Borzea, CNEE - CDEP, 2012);

- „Analiza programelor şi manualelor şcolare” (coord. L. Căpi ă, CNEE, E.D.P., 2012);

- „Repere pentru proiectarea şi actualizarea Curriculumului Na ional', Institutul de Ştiin e ale Educa iei, aprilie, 2015;

- „Contribu ii la teoria curriculumului: proiectarea documentelor reglatoare şi metodologice”, „Vasile Goldiş” University Press, 2015;

- „Geografie educa ională”, „Vasile Goldiş” University Press, 2017;

- „Elemente actuale de curriculum şi didactică” („Vasile Goldiş” University Press, 2017).

Pentru geografie şi domeniul de studiu „Geografie - mediu înconjurător” există în prezent (2017) un context sensibil modificat chiar în raport cu ini iativele relativ recente redate în „Competen ele în învă area geografiei” (2010), "Instruirea centrată pe competen e la geografie în învă ământul preuniversitar" (2012), , ,Geografie - curriculum şcolar” (2015), precum şi în alte lucrări recente (2014, 2016, 2017), în diferite documente şi articole publicate în această perioadă. 
În vederea proiectării unui curriculum disciplinar renovat redăm mai jos, într-o formă minimală, un sistem referen ial adaptat unui domeniu de studiu (geografie - mediu înconjurător). Acesta cuprinde mai multe categorii de repere şi repere individualizate.

\subsection{Repere primare (fundamentale, normative)}

1.1.1. Reperele teoretice (epistemologice) ale geografiei ca ştiin ă şi domeniu de studiu influen ează proiectarea unui nou curriculum (Mândru , 2010, 2012, 2013, 2014, 2016). Astfel, în sensul valorificării specificului ei ştiin ific, geografia trebuie considerată o ştiin ă:

a) atât a naturii cât şi a societă ii;

b) cu două mari domenii „clasice” (geografie fizică şi geografie umană), dar şi un obiect predilect integrat de studiu, mediul înconjurător - ca interac iune dintre om şi mediul său de via ă - la nivel global, regional şi local;

c) cu un sistem metodologic propriu de investigare a realită ii (îndeosebi a reprezentării spa iale, prin ilustrarea cartografică a realită ii şi a trecerilor de scară);

d) cu posibilită i foarte mari de ancorare a demersului explicativ în actualitatea lumii contemporane (mondializare, metropolizare, dezvoltare durabilă etc.).

1.1.2. Structura actuală (2017) a geografiei ca disciplină şcolară semnificativă în învă ământul preuniversitar influen ează sensibil orice fel de proiec ie nouă (în sens remanent), printr-o serie de elemente care îşi au originea în tradi ia acesteia (decupaje clasice, prezen a unor domenii consacrate, pozi ia geografiei ării, resursele de timp etc.).

1.1.3. Structura învă ământului preuniversitar are un caracter determinant prin etajele acestuia (5+4+4), care influen ează segmentele majore, nivelurile, grupele de ani şi clase, evaluările şi examenele etc.

1.1.4. Dezvoltarea stadială a personalită ii elevilor. Acest principiu (Jean Piaget, 1965, 1982) eviden iază o serie de stadii (pe vârste) în care sunt definite opera ii şi activită i intelectuale prevalente, determinante asupra proiectării „verticale”. Chiar dacă au avut loc modificări în activită ile de învă are caracteristice acestor „stadii”, ca efect al inser iei TSI, ele rămân ca un cadru general veridic.

1.1.5. Realizarea unei succesiuni în timp între învă area psihologică şi învă area logică; acest principiu (definit de G. W. Kneller, 1967, traducere: 1976) sugerează ca, în prima parte a şcolarită ii, învă area (şi ordonarea con inuturilor) să aibă o structură predominant psihologică (adică adaptată posibilită ilor elevului), iar în a doua parte a şcolarită ii să aibă o structură predominant logică (adică adaptată logicii interioare a ştiin ei). 
1.1.6. Utilizarea pe termen scurt $(2016$ - 2020) a sistemului conceptual presupus de competen ele - cheie sugerate de Comisia Europeană, cu ameliorările recente $(2010,2017)$.

1.1.7. Prevederile „Legii Educa iei Na ionale”(LEN) în forma ei actuală (2017), transformată, au un efect marginal. Re inem din LEN conceptul domeniilor de studii în locul „,ariilor curriculare”. Structura învă ământului din proiec ia ini ială a Legii (2011) ar fi imprimat un alt „curriculum vertical”, pe grupe de câte trei clase şi resurse mai mici de timp pentru disciplinele „clasice”.

\subsection{Repere secundare (asociate reperelor primare)}

1.2.1. Corelarea cu elemente semnificative din „Carta interna ională a educa iei prin geografie"(document U.I.G., 1993 şi 2016).

1.2.2. Analiza curriculum-ului şcolar actual din diferite ări. Trebuie să subliniem însă că nu este necesar „importul” unor anumite solu ii din ări cu un învă ământ aparent evoluat. Preocuparea ar putea fi legată îndeosebi de compatibilizarea geografiei din ara noastră cu cea din ări cu o cultură asemănătoare: Portugalia, Fran a. Aceste trei ări (România, Fran a, Portugalia) au spre finalul studiilor un curs integrat despre Europa, ara respectivă şi Uniunea Europeană. Din punct de vedere calitativ, curriculumul de geografie din ara noastră reprezintă un model „exportabil” în alte ări (şi nu invers).

1.2.3. Identificarea unor anumite transformări în structura geografiei ca ştiin ă şi domeniu al realită ii. Aceasta se reflectă într-o modificare aparentă a centrului de greutate al geografiei dinspre ştiin ele naturii spre ştiin ele socio-umane, prin reorganizări interne şi prin multiple abordări noi în raport cu domenii aparent tradi ionale sau independentizate. Totodată, geografia fizică se apropie (ca tematică şi mod de abordare) de Ştiin ele despre Pământ (Earth Sciences). 1.2.4. Identificarea unor transformări în sfera centrelor de interes ale elevilor pentru învă are. Din această perspectivă, este necesară trecerea accentuată din zona geografiei enciclopediste şi descriptive în zona geografiei de interes pragmatic pentru existen a cotidiană a elevilor care poate fi denumită, simplificat, „geografie cotidiană”.

1.2.5. O modificare radicală în percep ia publică asupra modalită ilor de învă are a geografiei a fost indusă de sistemele multimedia, tehnologia informa iei şi comunicării şi GIS, care permit accesarea unor date geografice din locuri diferite într-un timp real şi în raport cu interesul propriu. Această perspectivă diminuează foarte mult interesul pentru învă area de tip tradi ional, la clasă, sub forma unor ore şi lec ii structurate după criteriile cunoscute, în condi iile în care aproape toate informa iile pertinente pot fi accesate într-un mod nou. 1.2.6. Utilizarea unor elemente referen iale şi concrete din documente anterioare $(1993,1999,2005,2011,2012,2014,2017)$ referitoare la ,inovarea geografiei în învă ământul preuniversitar"; acestea au stat la baza inten iei 
ini iale (1995) şi ulterioare $(1999,2005,2016)$ de realizare a unei transformări mai profunde a geografiei (eşuată par ial în anul 1995).

1.2.7. Utilizarea constructivă a paradigmei educa ionale oferite de curriculum (sintetizată în diferite documente, în programele şcolare şi în ghidurile metodologice recente), precum şi a noilor abordări inovative din ştiin ele educa iei $(2011,2016)$.

1.2.8. Inser ia transdisciplinarită iişi mai ales momentul în care se va produce reprezintă un criteriu pentru o viziune radicală.

\subsection{Repere particulare (complementare)}

Acestea provin din specificul geografiei ca domeniu ştiin ific şi educa ional. 1.3.1. Pozi ia improprie a geografiei într-o „arie curriculară” ilegitimă, care eludează originea ei în sfera ştiin elor naturii.

1.3.2. Construirea unui domeniu de studiu aparent supradisciplinar (geografie - mediu înconjurător) ar fi o solu ie mai bună, chiar dacă „mediul înconjurător” este de fapt o "geografie spa ializată".

1.3.3. O legătură a geografiei şi a domeniului „geografie - mediu înconjurător” cu ,ştiin ele” (fizică, biologie, chimie, chiar matematică) este mai naturală.

1.3.4. Paradigma transdisciplinarită ii este izomorfă sub raport ştiin ific şi educa ional sistemului geografie - mediu înconjurător.

1.3.5. Deşi interesul pentru cultivarea educa ională a spa iului na ional s-a diminuat considerabil, acesta rămâne o preocupare notabilă a geografiei (şi istoriei) ării, cu men iunea că Geografia României trebuie să devină o „altă” geografie.

1.3.6. Dimensiunea ideologică a paradigmei curriculare („Curriculum ca ideologie" la Marsh, 2004), în contextul mondializării, poate fi adusă în discu ie cu elemente experien iale noi din alte ări, precum şi în raport cu logica disciplinelor „tari” (fizică, biologie, chimie, geografie fizică). Geografia poate deveni pentru secolul XXI o adevărată ideologie şi o paradigmă curriculară.

1.3.7. Definirea şi inser ia geografiei în sistemul unei culturi generale func ionale cu elemente anticipative.

1.3.8. Realizarea unui echilibru între dimensiunea locală, regională, na ională, europeană şi mondială a realită ii supuse aten iei; această oportunitate facilitează abordările integrate.

\subsection{Factori subiectivi}

În contextul de mai sus (1.1., 1.2., 1.3.), deşi concretizarea inovării în domeniul geografiei pare să aibă un anumit caracter aleator, proiectarea ei cât mai obiectivă reprezintă o datorie elementară a celor care activează în sfera geografiei educa ionale. 
La acest sistem referen ial se adaugă un mare număr de factori subiectividin sfera actorilor sociali şi politici şi îndeosebi din partea persoanelor care asigură proiectarea şi managementul sistemului educa ional; este de observat că, la acest nivel, există o percep ie predominant negativă asupra geografiei, par ial îndreptă ită, bazată însă frecvent pe o situa ie anterioară, remanentă. Subiectivitatea rezultă şi din opiniile divergente ale geografilor în cazul geografiei educa ionale şi al proiectării curriculumului.

\section{Tabelul 1. Factorii care determină renovarea curriculumului}

\begin{tabular}{|c|c|c|c|c|}
\hline $\begin{array}{l}\text { Repere selective ale } \\
\text { sistemului } \\
\text { referen ial }\end{array}$ & $\begin{array}{c}(\mathrm{A}) \\
\text { Situa ia } \\
\text { actuală } \\
(\mathbf{2 0 1 7})\end{array}$ & $\begin{array}{l}\text { (B) Proiec ie } \\
\text { ameliorativă } \\
\text { minimală } \\
(\text { sub 20\%) }\end{array}$ & $\begin{array}{c}(\mathbf{C}) \\
\text { Modificare } \\
\text { medie } \\
(20-30 \%)\end{array}$ & $\begin{array}{c}\text { (D) } \\
\text { Modificare } \\
\text { radicală } \\
\text { (reproiectare) }\end{array}$ \\
\hline Geografia ca ştiin ă & 2 & 3 & 3 & 4 \\
\hline $\begin{array}{l}\text { Geografia şcolară } \\
\text { actuală }\end{array}$ & 4 & 3 & 2 & 1 \\
\hline $\begin{array}{l}\text { Structura } \\
\text { învă ământului }\end{array}$ & 4 & 3 & 1 & 1 \\
\hline Dezvoltarea elevilor & 1 & 2 & 3 & 4 \\
\hline Psihologic şi logic & 1 & 2 & 3 & 4 \\
\hline Competen e & 2 & 2 & 1 & 0 \\
\hline LEN $(2011,2017)$ & 2 & 1 & 0 & 0 \\
\hline $\begin{array}{l}\text { Carta educa iei } \\
\text { (UIG) }\end{array}$ & 1 & 1 & 1 & 0 \\
\hline $\begin{array}{l}\text { Geografia în diferite } \\
\text { ări }\end{array}$ & 3 & 2 & 2 & 1 \\
\hline $\begin{array}{l}\text { Geografia } \\
\text { „cotidiană” }\end{array}$ & 1 & 2 & 3 & 4 \\
\hline Centre de interes & 1 & 2 & 3 & 4 \\
\hline TSI (prin TIC şi GIS) & 1 & 2 & 2 & 3 \\
\hline Proiecte anterioare & 2 & 1 & 2 & 2 \\
\hline Transdisciplinaritatea & 0 & 1 & 2 & $4(5)$ \\
\hline Alte finalită i & 0 & 0 & 1 & $3(4)$ \\
\hline Factori subiectivi & 3 & 2 & 1 & 0 \\
\hline
\end{tabular}


Cifrele de mai sus $(5,4,3,2,1)$ reflectă, cu o anumită aproxima ie, intensitatea legăturii dintre sistemul referen ial şi curriculum de geografie $(A-$ actual şi $B$, C, D posibil, în variante modificate).

Aceste sunt: 5 - legătură (aproape) determinantă, 4- legătură foarte strânsă; 3 - legătură importantă; 2 - legătură medie (bună); 1 - legătură slabă; 0 absen a legăturii.

\section{Sistemul de finalită i al geografiei şcolare}

Organizarea generativă, constructivistă, presupune formarea cumulativă a competen elor şi a sistemului axiologic pe o anumită durată de timp, pe mai multe niveluri $(\mathrm{N})$; aceste niveluri $\left(\mathrm{N}_{0}-\mathrm{N}_{6}\right)$ au în vedere întregul învă ământ preuniversitar.

Stabilirea sistemului de finalită i a avut la bază utilizarea, în prezent, a referen ialului presupus de competen e.

Competen ele generale $(1-12)$ pe care le avem în vedere sunt cele asumate în diferite documente anterioare; acestea se referă la programele şcolare de liceu (2004, 2007) şi cele de gimnaziu (2017), la care s-au adăugat alte competen e de un nivel mai înalt, referitoare mai mult la geografie ca ştiin ă (10) şi cariera profesională (11 - 12). Formulările de mai jos le exced pe cele din programele actuale.

\subsection{Competen ele generale (CG) ar putea fi:}

(1) Prezentarea realită ii înconjurătoare (cu elemente, procese, fenomene, sisteme, structuri şi interac iuni) utilizând limbaje diferite (competen a comunica ională, limbajul grafic şi cartografic);

(2) Rela ionarea elementelor semnificative din alte discipline şcolare sincrone cu dimensiunea spa ială şi realitatea înconjurătoare ca întreg;

(3) Utilizarea unor deprinderi şi metode de învă are care să fie utile educa iei permanente (ra ionamente ipotetice, modele, investiga ie ştiin ifică, explorări teoretice);

(4) Rela ionarea elementelor şi fenomenelor din realitate cu reprezentarea lor (cartografică, grafică, pe imagini satelitare sau modele);

(5) Utilizarea unei metodologii minimale de investigare a elementelor, fenomenelor, proceselor şi interac iunilor caracteristice realită ii înconjurătoare ca sistem func ional şi spa ial obiectiv;

(6) Perceperea constructivă a procesului de mondializare prin dimensiunea sa spa ială, interac ională şi cartografică; 
(7) Utilizarea elementelor de bază ale tehnologiei societă ii informa iei (TSI) şi GIS în accesarea, prelucrarea şi prezentarea informa iilor cu un con inut prevalent geografic;

(8) Corelarea (rela ionarea) dimensiunii culturale a existen ei umane cu spa iul locuit;

(9) Rela ionarea realită ilor din natură (şi din sfera ştiin elor despre natură) cu cele ale societă ii (şi din sfera ştiin elor despre societate) într-o structură obiectivă integrată;

(10) Prezentarea realită ii obiective rezultate din interac iunea dintre natură şi societate şi a geografiei ca disciplină (ştiin ă) de sinteză care studiază această realitate integrată;

(11) Utilizarea elementelor rezultate din învă area geografiei în via a cotidiană şi în pregătirea carierei profesionale ulterioare;

(12) Rezolvarea unor situa ii şi probleme practice de învă are şi de activitate cotidiană.

Sistemul de competen e va trebui negociat şi, eventual, asumat. Fiecare competen ă generală (CG) va fi concretizată într-un număr de competen e specifice (într-un total de 40 - 45), ordonate după vectorul progresului în învă are.

\subsection{Atitudini şi valori}

Acestui sistem de competen e generale îi este asociat un sistem de atitudini şi valori promovabile cu ajutorul geografiei care, pentru întregul parcurs şcolar, ar fi:

- Construirea unei atitudini pozitive fa ă de educa ie, cunoaştere, societate, cultură, civiliza ie;

- Dezvoltarea curiozită ii pentru explorarea realită ii înconjurătoare;

- Dezvoltarea respectului pentru diversitatea naturală şi umană;

- Construirea reperelor individuale pentru propria dezvoltare educa ională şi profesională;

- Dezvoltarea spiritului de colaborare, lucru în echipă şi a perseveren ei în activită ile de investiga ie sau de învă are.

Pot fi incluse şi alte componente atitudinale, în forme adecvate. Sistemul axiologic şi atitudinal poate fi ordonat, taxonomizat şi organizat în succesiunea vârstelor şi a componentei „competen e - con inuturi” din curriculum şcolar (Catană, 2013, 61 -69).

Competen ele cheie, considerate sursă a competen elor generale şi-au epuizat 
resursele „normative”, demonstrându-se limitele şi caracterul lor reduc ionist. Noile programe pentru clasele V - VIII s-au îndepărtat sensibil de acest sistem.

\subsection{Alte finalită $i$}

Trecerea de la „obiective generale şi de referin ă” la „competen e generale şi specifice" (2001 - 2009) s-a realizat mai mult ca rezultat al unei ini iative renovatoare ,în sine”, deoarece nu este demonstrată inutilitatea obiectivelor şi nici „superioritatea” educa ională a competen elor.

În viitorul apropiat (deceniul 3) este posibil să fie eviden iat rolul atitudinilor (ca finalită i „transversale”), iar apoi al „posibilită ii (capacită ii) de a face ceva” (adică al „capabilită ii” individuale).

\section{Tipuri de învă are, niveluri, vârste şi clase}

În prezent (2017), structura învă ământului preuniversitar sugerează o grupare pe „cicluri” de câte 4 ani (învă ământ primar, gimnazial şi liceal), fiecare cu câte două "niveluri” posibile de câte 2 ani $\left(\mathrm{N}_{0}-\mathrm{N}_{5}\right)$.

Modelul actual, utilizabil şi pentru alte discipline şcolare, în contextul învă ământului preuniversitar, cu etapele presupuse de tipurile predominante de învă are şi nivelurile de performare, poate fi redat grafic astfel:

Tabelul 2. Vârste, clase, niveluri şi tipuri de învă are

\begin{tabular}{|c|c|c|c|}
\hline $\begin{array}{c}\text { Vârste } \\
\text { (aproximativ) }\end{array}$ & Clase & $\begin{array}{l}\text { Niveluri } \\
\text { generale }\end{array}$ & $\begin{array}{l}\text { Tipuri predominante } \\
\text { de învă are (etape) }\end{array}$ \\
\hline$>18$ & XII & \multirow{2}{*}{$\mathrm{N}_{5}$} & \multirow{2}{*}{$\begin{array}{l}\text { Învă are ,pragmatică” } \\
\text { (dimensiunea „,utilitară”) }\end{array}$} \\
\hline $17-18$ & XI & & \\
\hline $16-17$ & $\mathrm{X}$ & \multirow[b]{2}{*}{$\mathrm{N}_{4}$} & \multirow{2}{*}{$\begin{array}{l}\text { Învă are „logică” } \\
\text { (adecvată structurilor } \\
\text { logice ale ştiin ei) }\end{array}$} \\
\hline $15-16$ & IX & & \\
\hline $14-15$ & VIII & \multirow{2}{*}{$\mathrm{N}_{3}$} & \multirow{2}{*}{$\begin{array}{l}\text { Învă are psihologică şi } \\
\text { logică }\end{array}$} \\
\hline $13-14$ & VII & & \\
\hline $12-13$ & VI & \multirow{2}{*}{$\mathrm{N}_{2}$} & \multirow{2}{*}{$\begin{array}{l}\text { Interferen } \breve{a} \text { (psihologic } / \\
\text { logic) }\end{array}$} \\
\hline $11-12$ & $\mathrm{~V}$ & & \\
\hline $10-11$ & IV & \multirow{2}{*}{$\mathrm{N}_{1}$} & \multirow{5}{*}{$\begin{array}{l}\text { Învă are ,psihologică”, } \\
\text { (adecvată structurilor } \\
\text { psihologice ale elevului şi } \\
\text { învă ării) }\end{array}$} \\
\hline $9-10$ & III & & \\
\hline $8-9$ & II & \multirow{3}{*}{$\mathrm{N}_{0}$} & \\
\hline $7-8$ & I & & \\
\hline $6-7$ & 0 (,pregătitoare”) & & \\
\hline
\end{tabular}


Este evident că acest model influen ează structura „verticală” a proiectării curriculum-ului şi a instruirii.

Din punctul de vedere strict al geografiei şcolare, aceste niveluri „generale” (adică adaptabile pentru orice disciplină şcolară din învă ământul preuniversitar) pot fi particularizate în următoarea formă:

$\begin{array}{lllll} & \text { Nivel } & \text { Clase } & \text { Tipuri de învă are } & \text { Tip de ,geografie” } \\ \mathrm{N}_{1} & \begin{array}{l}\text { Nivelul } \\ \text { introductiv }\end{array} & \text { III-IV } & \text { Învă are psihologică } & \text { observa ională } \\ \mathrm{N}_{2} & \text { Nivel elementar } & \text { V-VI } & \text { Psihologic/logic } & \text { investiga ie elementară } \\ \mathrm{N}_{3} & \text { Nivel mediu } & \text { VII-VIII } & \text { Învă are psihologică şi logică } & \text { indirectă } \\ \mathrm{N}_{4} & \text { Nivel superior } & \text { IX-X } & \text { Învă are logică } & \text { ştiin ifică } \\ \mathrm{N}_{5} & \text { Nivel înalt } & \text { XI-XII } & \text { Învă are ,pragmatică” } & \text { ştiin ifică şi utilitară }\end{array}$

Pentru fiecare nivel $\left(\mathrm{N}_{1}-\mathrm{N}_{5}\right)$ competen ele generale au un caracter „adaptat” fa ă de formularea generică $(1-12)$. Sistemul atitudinal şi axiologic are o altă logică de construc ie. Pentru clasele IV - VIII, sistemul de finalită i (competen e) a fost construit (2017) şi este pus în aplicare. Pentru ciclul liceal (clasele IX XII), într-o perspectivă apropiată, acest sistem ar fi:

\subsection{Nivelul 4 (superior): Clasele IX - X; vârsta 15 - 17 ani}

La acest nivel se dezvoltă şi se consolidează „gândirea rela ională” (cauzală), care permite identificarea interac iunilor dintre elementele, fenomenele şi procesele din mediul înconjurător şi constituirea lor în structuri, sisteme şi interac iuni. Prin natura posibilă a disciplinelor şcolare (Geografie fizică şi elemente de Ştiin ele Pământului şi Geografie umană şi a mediului înconjurător) pot fi puse bazele „învă ării ştiin ei” (adică a învă ării geografiei ca ştiin ă şi a disciplinelor conexe), la un nivel teoretic corespunzător.

\section{Competen e generale: 1 - 8}

Con inuturi posibile:

- Elemente ale geografiei ca ştiin ă (geografie fizică, geografie umană, geografie integrată, geografie regională);

- Elemente ale geografiei ca ştiin ă a naturii şi a Ştiin elor Terrei;

- Elemente ale geografiei ca ştiin ă social-umană;

- Elemente ale geografiei mediului înconjurător şigeoecologie;

- Dimensiunea spa ială a realită ii studiate (lumea ca întreg, Europa, ara, regiunea); geografie cotidiană; 
- Interac iuni naturale, umane şi interac iuni globale între natură şi societate (geosisteme, regiuni, peisaje, circuite).

\subsection{Nivelul 5 (înalt): Clasele XI - XII; vârsta 17 - 18 ani}

La acest nivel are loc 0 dezvoltare calitativă nouă a procesului de învă are şi de gândire, în care are loc afirmarea gândirii cauzale. Totodată dimensiunea pragmatică, utilitară, devine predominantă, învă area fiind orientată în mod utilitar spre continuarea educa ională şi profesională (BAC, admitere în învă ământul superior, rută voca ională).

Competen e generale: $1-12$ (competen ele generale $9-12$ sunt adăugate în raport cu nivelul anterior)

Con inuturi posibile:

- Elemente de bază ale procesului de mondializare şi metropolizare;

- Interac iuni, rela ii, structuri şi sisteme în lumea contemporană;

- Elemente interdisciplinare şi supradisciplinare referitoare la geografie;

- Elemente de interac iune între problematica lumii contemporane, a Europei, Uniunii Europene şi României;

- Terra: dimensiunea spa ială a scenariilor de evolu ie în viitor;

- Raportul dintre mondializare şi conservarea identită ii;

- Provocări noi ale interac iunilor globale; geografie cotidiană;

- Dezvoltarea durabilă la diferite scări de reprezentare;

- Elemente de geopolitică şi geostrategie.

- Cultură, civiliza ie şi viitorul omenirii.

\section{Proiectarea formării competen elor generale}

Prezen a acestor competen e generale $(1-12)$ şi modul lor de realizare sunt men ionate la fiecare nivel $\left(\mathrm{N}_{1}-\mathrm{N}_{6}\right)$ prin anumite nuan ări terminologice („Geografie - curriculum şcolar”, 2015). Competen ele generale vizează ansamblul învă ământului preuniversitar conservând, în linii mari, şi accep iunile acordate acestora în programele şcolare actuale. Noile programe pe competen e pentru gimnaziu (2017) au o coloratură terminologică pu in diferită şi au un aspect minimal, aparent reduc ionist.

Această construire cumulativă a competen elor în timp poate fi redată şi într-o formă grafică intuitivă, prezentată în continuare. 
Tabelul 3. Formarea competen elor în timp

\begin{tabular}{|c|c|c|c|c|c|}
\hline \multirow{2}{*}{$\begin{array}{c}\text { Competen e } \\
\text { generale }\end{array}$} & \multicolumn{5}{|c|}{ Caracteristici calitative ale competen elor } \\
\cline { 2 - 6 } & $\mathbf{N}_{1}$ & $\mathbf{N}_{2}$ & $\mathbf{N}_{3}$ & $\mathbf{N}_{4}$ & $\mathbf{N}_{5}$ \\
\hline$(1)$ & $\bullet$ & $\bullet$ & $\bullet \bullet$ & $\bullet \bullet$ & $\bullet \bullet \bullet$ \\
\hline$(2)$ & $\bullet$ & $\bullet$ & $\bullet \bullet$ & $\bullet \bullet$ & $\bullet \bullet \bullet$ \\
\hline$(3)$ & $\bullet$ & $\bullet$ & $\bullet \bullet$ & $\bullet \bullet \bullet$ & $\bullet \bullet \bullet$ \\
\hline$(4)$ & $\bullet$ & $\bullet$ & $\bullet$ & $\bullet \bullet$ & $\bullet \bullet \bullet$ \\
\hline$(5)$ & $\bullet$ & $\bullet$ & $\bullet \bullet$ & $\bullet \bullet \bullet$ & $\bullet \bullet \bullet$ \\
\hline$(6)$ & & $\bullet$ & $\bullet$ & $\bullet \bullet$ & $\bullet \bullet$ \\
\hline$(7)$ & & $\bullet$ & $\bullet$ & $\bullet \bullet$ & $\bullet \bullet$ \\
\hline$(8)$ & & $\bullet$ & $\bullet$ & $\bullet \bullet$ & $\bullet \bullet$ \\
\hline$(9)$ & & & & & $\bullet \bullet$ \\
\hline$(10)$ & & & & & $\bullet \bullet$ \\
\hline$(11)$ & & & & & $\bullet$ \\
\hline$(12)$ & & & & & $\bullet$ \\
\hline
\end{tabular}

Structura interioară calitativă a modului de formare a competen elor se referă la:

- $\quad$ nivel elementar (bazat pe percep ie directă, nestructurată)

-• nivel mediu (concretizat în demonstrarea în elegerii realită ii)

•.• nivel superior (concretizat în explicarea structurată a realită ii)

Pentru fiecare competen ă generală $(1$ - 12) pot fi urmărite, pe baza acestui tabel, următoarele elemente:

- $\quad$ nivelurile de învă are $\left(N_{1}-N_{5}\right)$, care consemnează modul de formare a competen ei în timp;

- caracteristicile calitative ale competen ei (nivel elementar, mediu, superior);

- diferen ele între competen ele generale (1 - 12) în ceea ce priveşte gradul lor de complexitate;

- posibilitatea (şi oportunitatea) formării lor în timp;

- descrierea competen elor pe niveluri (şi, eventual, clase) poate induce şi vectorul de „progres al învă ării”.

Raportarea competen elor generale la nivelurile de realizare trebuie să fie detaliată pentru fiecare componentă interioară a acestora şi prin competen ele specifice derivate.

Curriculum şcolar actual (2005 - 2017) are următoarea structură tematică verticală (modulul A): 
Tabelul 4. Disciplinele şcolare din liceu

\begin{tabular}{|l|r|l|}
\hline \multicolumn{2}{|c|}{ Niveluri şi clase } & \multicolumn{1}{l|}{ Titluri disciplinare (denumiri simplificate) } \\
\hline \multirow{2}{*}{ Nivelul (5) } & XII & Europa - România - Uniunea Europeană \\
\cline { 3 - 4 } & XI & Lumea contemporană - Probleme fundamentale \\
\hline \multirow{2}{*}{ Nivelul (4) } & X & Geografie umană \\
\cline { 3 - 4 } & IX & Geografie fizică \\
\hline \multirow{2}{*}{ Nivelul (3) } & VIII & Geografia României \\
\cline { 3 - 3 } & VII & Continentele extraeuropene \\
Nivelul (2) & VI & Terra - elemente de geografie umană. Europa \\
\cline { 3 - 3 } & V & Terra - elemente de geografie fizică \\
\hline \multirow{2}{*}{ Nivelul (1) } & IV & Introducere în geografie \\
\cline { 3 - 3 } & III & Ştiin e ale naturii (III - IV) \\
\hline
\end{tabular}

(Tabelul se citeşte de jos în sus)

\section{Structura modulară ca op iune pentru un curriculum ameliorat}

În conformitate cu op iunea organizării tematicii generale (competen e şi con inuturi) într-o structură „modulară”, pot fi construite module „mari” (notate cu M) şi module „mici” (notate cu $m$ ). Modulele „mici” $\left(m_{3}\right.$ şi $\left.m_{7}\right)$ au un pronun at caracter de sinteză şi evaluare. În situa ia unor resurse minime de timp (o oră pe săptămână), modulele predominant de instruire $\left(M_{1}, M_{2}, \ldots M_{6}\right)$ pot fi asimilate, cu aproxima ie, unor unită i de învă are.

Proiectarea multianuală pentru ciclul liceal (IX - XII) poate fi segmentată pe două niveluri de învă are: $N_{4}$ (pentru ciclul liceal inferior, IX $-X$ ) şi $N_{5}$ (pentru ciclul liceal superior, XI-XII).

Structura actuală (2017) este adecvată caracteristicilor tipurilor predominante de învă are:

- în ciclul liceal inferior, geografia actuală (fizică şi umană) acoperă, prin caracterul teoretic şi ştiin ific al con inuturilor, caracterul „logic” al învă ării, de „învă are a ştiin ei”;

- în ciclul liceal superior, „Probleme fundamentale ale lumii contemporane” (clasa a XI-a) şi „Europa - România - Uniunea Europeană” (clasa a XII-a) au un pronun at caracter ştiin ific, dar şi utilitar, pragmatic, atât pentru experien a personală de via ă, cât şi pentru traseul educa ional ulterior. 
Structura modulară a geografiei a făcut obiectul unor dezvoltări corespunzătoare (Mândru \& Dan, 2014, 2015), pe care nu le mai reluăm aici. Nota iile sunt reluate mai jos (6.1., 6.2.).

\section{Proiectarea unui nou curriculum de geografie pentru ciclul liceal}

Variantele structurii verticale pe care le poate avea succesiunea disciplinelor şcolare în contexte diferite sunt determinate de interac iunea factorilor men iona i anterior (tabelul 1). Pentru ciclul secundar inferior (gimnaziu, clasele V - VIII) varianta actuală (aprobată în anul 2017) are caracteristicile cunoscute şi este în curs de aplicare.

Pentru ciclul secundar superior (liceu), în raport cu varianta actuală (A), prezentăm două variante: $(B)$ o proiec ie ameliorativă minimală şi $(C)$ o proiec ie care presupune o modificare medie. Proiectarea radicală (D) este presupusă de inser ia transdisciplinarită ii, implicând o altă abordare.

\subsection{Variantă renovată $(B)$ : proiec ie ameliorativă minimală - Clasele IX - XII}

Tabelul 5. Modulele tematice din ciclul liceal, proiec ie ameliorativă minimală (B)

\begin{tabular}{lcll}
\hline \multicolumn{1}{c}{ Clasa } & Modul & \multicolumn{1}{c}{ Titlul modulului } \\
\hline a XII-a & $M_{7}$ & Geografia culturală şi socială a României şi a Europei \\
& $M_{6}$ & România şi Europa - geografie cotidiană \\
Europa, România, & $\mathrm{M}_{5}$ & România şi Uniunea Europeană în contextul mondializării \\
Uniunea Europeană & $\mathrm{M}_{4}$ & România - elemente actuale ale integrării europene \\
(Probleme & $\mathrm{M}_{3}$ & Uniunea Europeană (caracteristici comune şi ări) \\
fundamentale) & $\mathrm{M}_{2}$ & România în Europa: caracteristici geografice \\
& $\mathrm{M}_{1}$ & Europa: elemente caracteristice ale spa iului geografic \\
\hline & $M_{7}$ & Geografie culturală şi socială; Geografie cotidiană \\
a XI-a & $M_{6}$ & Terra - scenarii de evolu ie \\
& $\mathrm{M}_{5}$ & Grupări regionale de state \\
Lumea & $\mathrm{M}_{4}$ & State semnificative în lumea contemporană \\
contemporană & $\mathrm{M}_{3}$ & Elemente de geopolitică şi organizarea spa iului mondial \\
(Probleme & $\mathrm{M}_{2}$ & Dezvoltarea durabilă în context spa ial \\
fundamentale $)$ & $\mathrm{M}_{1}$ & Procesul de mondializare şi metropolizare \\
\end{tabular}




\begin{tabular}{lcll}
\hline \multicolumn{1}{c}{ Clasa } & Modul & & \multicolumn{1}{c}{ Titlul modulului } \\
\hline a X-a & $\mathrm{M}_{7}$ & Modificări globale actuale ale mediului \\
Geografie umană şi a & $\mathrm{M}_{6}$ & Mediul înconjurător (tipuri de medii) şi conservarea lui \\
mediului & $\mathrm{M}_{5}$ & Mediul înconjurător (factorii geoecologici) \\
înconjurător (Terra, & $\mathrm{M}_{4}$ & Geografie economică mondială (elemente de bază) \\
Europa, România) & $\mathrm{M}_{3}$ & Resursele Terrei (poten ialul natural) \\
& $\mathrm{M}_{2}$ & Geodemografie şi habitatul uman (aşezări) \\
\hline a IX-a & $\mathrm{M}_{1}$ & Elemente de geografie politică \\
Geografie fizică & $\mathrm{M}_{6}$ & Terra ca sistem autoreglabil şi antientropic. \\
şi elemente de & & Antropogeosfera \\
Ştiin ele Pământului & $\mathrm{M}_{5}$ & Zone şi peisaje naturale \\
(Terra, Europa, & $\mathrm{M}_{4}$ & Geosisteme (sisteme de materie şi energie pe Terra) \\
România) & $\mathrm{M}_{3}$ & Elemente de geografie fizică generală (pe geosfere) \\
& $\mathrm{M}_{2}$ & Terra şi Ştiin ele Pământului: elemente de bază \\
& $\mathrm{M}_{1}$ & Pământul ca planetă. Reprezentarea suprafe ei terestre \\
\hline
\end{tabular}

(Tabelul se citeşte de jos în sus)

La clasele IX, X, XI, abordarea este în concordan ă cu paradigma scalară: Terra - Europa - România. La clasele XI-XII, numărul de module este mai mare, deoarece resursele obligatorii de timp pot să fie mai mari (TC + CDS). Aceste module posibile sunt semnalate mai sus cu litere italice.

În fiecare clasă va exista un modul integrat, denumit provizoriu - Geografie cotidiană.

Competen ele specifice derivate din competen ele generale $(1-12)$, precum şi sistemul atitudinal valoric vor fi adaptate celor două niveluri anterioare (clasele IX - X, respectiv XI - XII) şi tipului predominant de învă are. Vor fi abordate în mod prevalent competen ele generale „noi” $(10-12)$, cele mai înalte pentru „învă area” geografiei.

\subsection{Varianta $\mathbf{C}$ (proiec ie cu modificare medie)}

Varianta „medie” presupune o formă cu elemente inovative mai clare decât cea anterioară (1), cuprinzând:

- diminuarea influen ei structurii actuale;

- ,independentizarea” fa ă de structura învă ământului;

- accentuarea preocupărilor pentru domeniile de interes ale elevilor, urmărirea (şi) altor finalită i;

- creşterea ponderii învă ării transdisciplinare şi rearanjarea curriculumului. 
Acest ultim criteriu este determinant şi presupune, conform modelului prezentat anterior:

(a) Transformarea activită ilor de învă are specifice transdisciplinarită ii într-un sistem detaliat de competen e - atitudini - capacită $i$, sub forma unor finalită i (exigen e) bine exprimate, generative (de la 1 la n).

(b) Transformarea exemplelor de con inuturi chiar în con inuturi predominant disciplinare, într-o ordine prescrisă de „activită ile de învă are” şi nu de structura „academică” a ştiin ei, într-o formă centrată pe o „tematică de învă are" (nu capitole disciplinare).

\subsection{Varianta D (radicală)}

Varianta „radicală” presupune o reproiectare determinată de:

- un sistem nou de finalită i (capacită i sau „ce este capabil elevul să facă”);

- construirea con inuturilor dintr-o perspectivă „utilitară” învă ării (fără vectorul geografiei tradi ionale sau academice);

- adaptarea ofertei geografiei (capacită i-con inuturi-activită i de învă are) la un sistem de credite;

- caracterul predominant op ional al unor domenii (discipline) „clasice” ofertate în cadrul unor structuri mult mai largi (ştiin e, studii sociale);

- organizarea învă ării (şi a curriculumului) pe succesiunea şi logica demersurilor cognitive transdisciplinare.

Este posibil ca această versiune ,radicală”:

- să fie aplicată peste câteva decenii (2030 - 2040);

- să fie aplicată ini ial pe un segment al învă ământului (de exemplu, pentru ciclul liceal superior sau cum va fi denumit acesta în momentul respectiv);

- să fie îmbinat sistemul evaluărilor obligatorii (la anumite discipline sau domenii de studii) cu accesarea complementară a unor „credite”;

- să nu fie aplicată niciodată, ca efect al presiunii utilizatorilor.

\section{Elemente de op iune şi dezvoltare curriculară}

Op iunea pentru un anumit model presupune o succesiune în timp, de la situa ia actuală $(A)$, la varianta renovată minimal $(B)$, apoi la o variantă ,medie” (C) şi o variantă „radicală” (D).

Varianta „minimală” (B) presupune o anumită rearanjare interioară a sistemului de competen e-con inuturi, cu o coloratură actualizată a diviziunilor interioare şi introducerea unor teme de interes.

Varianta „medie” (C) implică transformări structurale mai mari, provenite din organizarea con inuturilor într-o legătură mai strânsă cu activită ile intelectuale transdisciplinare. 
Varianta „radicală” (D) presupune modificarea substan ială a curriculumului „vertical” (IX - XII), prin elementele men ionate.

În toate situa iile este necesară o racordare la sistemul supraordonat (finalită i, cicluri, clase, coloratura disciplinară, domenii etc.), legisla ie etc.

Criteriile de construc ie $(1.1 ., 1.2 ., 1.3$.$) pot avea modificări în raport cu acest$ referen ial supraordonat.

De la construirea unei taxonomii a competen elor (prin negociere) va trebui să se treacă la elaborarea altor finalită i; de asemenea, va trebui extinsă şi taxonomizată descrierea demersurilor intelectuale transdisciplinare.

Creşterea con inuturilor prin „acre ie” va trebui să fie înlocuită cu un sistem de selectivitate ra ională, în acord cu elemente ale educa iei permanente şi ale „culturii generale anticipative”. În orice situa ie, va fi util un curriculum op ional actualizat şi adaptat interesului elevilor (redat, par ial, în „Geografie educa ională", 2017); de asemenea, suporturi de instruire, standarde şi un program de formare continuă pentru utilizatori.

\section{REFERIN EBIBLIOGRAFICE}

Ardelean, A., \& Mândru , O. (2016). Contribu ii la proiectarea documentelor normative ale Curriculumului Na ional: planuri şi programe, Studia Universitatis „Vasile Goldiş”, Ştiin e ale Educa iei, 3(2).

Catană, L. (2013). Componenta atitudinal - valorică în curriculum actual. În O. Mândru (Coord.), Curriculum şi didactică (63-71). Arad: „Vasile Goldiş” University Press.

Centrul de Didactică şi Educa ie Permanentă. http://www.uvvg.ro/cdep, pagina de publica ii, 2012 - 2017.

Clifford, N., Holloway, S., Rice, S., \& Valentine, G. (Eds.). (2011). Key Concepts in Geography. Londra: Sage.

D'Hainaut, L. (1981). Linii de for ă ale elaborării unui curriculum. În Programe de învă ământ şi educa ia permanentă (trad.). Bucureşti: E.D.P.

D'Hainaut, L. (1985). Des fins aux objectifs de l'Education. Paris: Nathan.

Graves, N. (Ed.). (1978). Curriculum Planning in Geography. Londra: Heineman Educ. Book Itd.

International Geographical Union (IGU). (1993, 2016). Interna ional Charter on Geographical Education. http://www.igu-cge.org.

Kneller, G. F. Logica şi limbajul educa iei. Bucureşti: E.D.P., (edi ia ini ială: 1967, traducere: 1976).

Lambert, D., \& Jones, M. (Eds.). (2013). Debates in Geography Education. Londra: Routledge. 
Marsh, C. I. (2004). Key Concepts for Understanding Curriculum. Londra, New York: Rutledge - Falmer, https://doi.org/10.4324/9780203326893.

Mândru , O. (2010). Competen ele în învă area geografiei. Ghid metodologic. Bucureşti: Editura Corint.

Mândru , O. (2012). Instruirea centrată pe competen e la geografie în învă ământul preuniversitar (suport de formare). Arad: „Vasile Goldiş” University Press.

Mândru , O. (2013). Reperele teoretice ale geografiei, ca sursă de renovare a curriculumului şcolar. Terra, XLIV, $1-2$. Bucureşti: CD Press.

Mândru, O. (2014). Elemente de epistemologie a geografiei. Arad: Vasile Goldiş" University Press.

Mândru ,O. (2016). Theoretical Benchmarks of Geography as renewal resource for Educational Curriculum, laşi: Lucrările Seminarului de Geografie „Dimitrie Cantemir" nr. 41.

Mândru , O. (2017). Geografie educa ională. Arad: „Vasile Goldiş” University Press.

Mândru , O. (2017). Realizări, limite, oportunită i şi posibilită i ale dezvoltării geografiei educa ionale din România la începutul sec. XXI, Terra, XLVIII, $1-2$, Bucureşti: CD Press.

Mândru , O. (2017, 13-15 octombrie). Proiectarea unui nou curriculum de geografie în învă ământul liceal. laşi: Seminarul Interna ional de Geografie „Dimitrie Cantemir”.

Mândru , O. (Coord.). (2017). Elemente actuale de curriculum şi didactică. Arad: „Vasile Goldiş” University Press.

Mândru ,O., \& Ardelean, A. (2015). Contribu ii la teoria curriculumului:Proiectarea documentelor reglatoare şi metodologice, Arad: „Vasile Goldiş” University Press.

Mândru , O., \& Dan, S. (2014). Didactica geografiei. Bucureşti: Editura Corint Educa ional.

Mândru , O., \& Dan, S. (2015). Geografie-curriculum şcolar-ghid metodologic. Bucureşti: Editura Corint Educa ional.

Mândru , O., \& Mândru , M. (2013). Transdisciplinaritatea - un model integrat de abordare a instruirii. Revista de Pedagogie - Journal of Pedagogy, $L X I(4)$.

MEN, CNC, Programele şcolare de geografie pentru clasele IV - XII. www.edu.ro. MEN, CNC. (1998). Curriculum na ional pentru învă ământul obligatoriu -cadru de referin ă. Bucureşti: Corint.

Negre -Dobridor, I. (2005). Didactica Nova. Bucureşti: Editura Aramis.

Negre -Dobridor, I. (2008). Teoria generală a curriculumului educa ional. laşi:

Editura Polirom.

Piaget, J. (1965). Psihologia inteligen ei. Bucureşti: Editura Ştiin ifică. 
Piaget, J. (1982). Psihologie şi pedagogie. Bucureşti: E.D.P.

Seguin, R. (1991). Elaboration et mise en oeuvre des programmes scolaires, guide méthodologique. UNESCO.

Stoica, A., \& Mihail, R. (2006). Evaluarea educa ională. Inova ii şi perspective. Bucureşti: Editura Humanitas Educational.

The online version of this article can be found at: http://revped.ise.ro/category/2017-en/

\section{(c) $(1)(0)$}

This work is licensed under the Creative Commons Attribution-NonCommercialShareAlike 4.0 International License.

To view a copy of this license, visit http://creativecommons.org/licenses/by-ncsa/4.0/ or send a letter to Creative Commons, PO Box 1866, Mountain View, CA 94042,
Versiunea online a acestui articol poate fi găsită la: http://revped.ise.ro/category/2017-ro/

\section{@@(}

Această operă este pusă la dispozi ie sub licen a Creative Commons AttributionNonCommercial-ShareAlike 4.0 International.

Pentru a vedea o copie a acestei licen $e$, vizita $i$ http://creativecommons.org/licenses/by-ncsa/4.0/ sau trimite i o scrisoare către Creative Commons, PO Box 1866, Mountain View, CA 94042, SUA. 